\title{
Management accounting: An instrument for implementing effective corporate governance
}

\author{
Mayanja MK and Van der Poll HM \\ Department of Management Accounting, Unisa, Pretoria, 0003 South Africa. \\ Accepted 28 September, 2011
}

\begin{abstract}
Management accounting is not given sufficient emphasis, at the board level, as a provider of timely and relevant information to facilitate the execution of good corporate governance. Without management accounting information corporations in Botswana may find it difficult to create sustainable corporate governance. A qualitative approach using questionnaires and interviews were used to establish the extent to which management accounting tools are applied by the directors in the target companies. The research was carried out amongst listed companies on the stock exchange and the parastatal companies in Botswana. Furthermore documentation, for instance annual financial statements from the companies were reviewed. Most directors in the companies do not fully utilise the tools of management accounting in decision making. Management accountants have also failed to provide the relevant information to the board. To execute their duties efficiently, directors may need to call for the management accounting reports from the senior management level up to the board level and regularly use these reports to facilitate decision making.
\end{abstract}

Key words: Management accounting, corporate governance.

\section{INTRODUCTION}

Management accounting, which was traditionally intended for internal use in companies has through its ability to measure value and present both current and forwardlooking information, developed into a key instrument to companies for delivering effective corporate governance to all stakeholders. The Chartered Institute of Management Accountants (CIMA, 2005) defines management accounting as the practice to measure, identify, accumulate, analyse, prepare, interpret and communicate information to management to assist them in the planning, evaluating and controlling of the company and to guarantee the proper use of and "accountability for its resources". Management accounting also involves the preparation of financial reports for groups such as shareholders, creditors, regulatory agencies and tax authorities which are not involved in the management of

\footnotetext{
${ }^{\star}$ Corresponding author. E-mail: Vdpolhm@unisa.ac.za.
}

Abbreviations: ROI, Return on investment; ROCE, return on capital employed. the company. Hence, it can be argued that management accounting may assist the board of directors in providing a realistic measurement of the company's current value, therefore, showing where the company is at a particular time.

CIMA (Insight, 2009) further defines management accounting as the practical science of creating value within private and public sector companies. Brewer et al. (2009) stated that, it is important to recognise the time value of money when evaluating projects. It is also expected that financial projection techniques of management accounting may provide a realistic value of the future position a company aims to achieve, therefore, enabling the board to deliver on their mandate of effective corporate governance.

Verhezen and Morse (2009) define corporate governance as: the interactions between coalitions of internal and external actors and the board members in directing and steering a corporation for value creation. It is important to note that the underlying objective of good corporate governance is to create, maintain or enhance value for the respective stakeholders. Corporate governance therefore, may only be effective if it ultimately 
creates value for its stakeholders. An effective corporate governance system may need boards of directors (executive and non-executive) who should be able to fulfil the following five responsibilities as pointed out by Kaplan and Nagel (2004):

1. Approve and monitor company strategy.

2. Approve major financial decisions.

3. Select the CEO; evaluate the CEO and senior executive team; and ensure executive succession plans.

4. Provide counsel and support to the CEO.

5. Ensure compliance.

In order to fulfil the above responsibilities, the board may need a competent management accounting function to facilitate its operations. CIMA (2003) indicated that financial reports lead to an information overload of the board and suggested that they need information based on the health of the company to understand where it is heading. Management accounting tools and reports may be able to supply the relevant information to the board.

Charan (2005) observed that, most boards of directors were in a state of instability and are still not living up to their potential of providing truly good governance and that governance does not only prevent misdeeds but actually improves the stakeholder value of the corporation. The term stakeholder was defined by Freeman (2010) as individuals or groups who can influence or are influenced by the actions decisions, policies, practices, or goals of the company. This definition and the increasing demand for transparency by the same stakeholders have made the internal boundaries of companies virtually nonexistent.

This research article addresses the extent to which companies in Botswana use management accounting to facilitate the achievement of effective corporate governance, by assisting the boards to fulfil their responsibilities. A literature review of the management accounting tools and techniques to facilitate corporate governance, identifying the critical decisions that directors are expected to make when practicing good corporate governance (Kaplan and Nagel, 2004) are look unto.

\section{LITERATURE REVIEW}

A director's responsibilities in effecting corporate governance were identified based on recommendations from: the United Kingdom Combined Code (UKCC) (FRC, 2010) on corporate governance, the King III report (2009) together with its code of best practice and the statutory requirements of the Sarbanes-Oxley (SOX) act (2002) of the United States of America.

In the following subsections the various management accounting tools and techniques which can be employed to facilitate corporate governance are discussed.

\section{Approving and monitoring company strategy}

Management accounting comprises a set of tools and techniques to support planning, decision making and control in business companies (Collier, 2009). Hence, management accounting ought to be of immense value to the board of directors in formulating and controlling the strategy of a company.

\section{Strategy formulation}

The King III report (2009) recommended, under Principle 1.4 , that a board should play a prominent role in the strategy development process and should not be the mere recipient of a strategy proposed by the management. In the view of Cadbury (2002), a board is responsible for the strategy of the business and for harmonising the operating plans and targets required to turn the strategy into action. UKCC (FRC, 2010) endorsed this view when it recommended that the board should set the company's strategic aims.

In order for the board to fulfil the corporate governance recommendations regarding strategy, it should, according to Kaplan and Nagel (2004), understand the strategic objectives of a company and be able to judge whether the strategy is capable of delivering long-term shareholder value at acceptable levels of business, financial and technological risk. Some of the management accounting tools which may be employed in the formulation of a strategy includes:

1. SWOT analysis: Management accounting may play a vital role in making meaningful forecasts and quantifying the effects of changes to the company using various techniques to quantify the threats and highlight them to the board for immediate attention (Johnson et al., 2008). On the other hand, management accounting may also assist in estimating the value of the opportunities for the board to justify the commitment of the company's resources to pursue such opportunities.

2. PESTEL framework: Using various costing and valuation techniques, the management accounting report may assign values and weights to the factors identified in a PESTEL framework, hence highlighting the key drivers of change. These may be the forces likely to affect the structure of an industry, sector or market (Johnson et al., 2008). This framework may assist the board in deciding how much of the companies resources to allocate to address the respective factors.

3. Porter's five competitive forces model: The management accounting reports issued to the directors using the Porter's five forces model (Porter, 1985) may attach costs and values to the powers and threats of the various elements mentioned above to enable the board to decide whether to ignore them or to dedicate time and funds to address them. Reports generated with the use of 
the abovementioned tools may empower the directors with objective information about the environment in which the company operates, thereby enabling the directors to make meaningful contributions or criticisms to the strategy formulation debate of the company, fulfilling one of their corporate governance functions.

\section{Monitoring and controlling strategy}

A general nature of control, according to Hoque (2006), is that, it places emphasis upon performance and the monitoring of activities that facilitate the accomplishment of a company's objectives. Charan (2005) and Pun and White (2005) emphasised that in order to monitor performance of a company, the management and the board should first identify the critical activities that drive future financial results and find a way to measure them.

Cingula (2006) writes that controlling is an important process within corporate governance, and all stakeholders who follow performance results of companies engaged in public well-being, should recognise the importance of control. Management accounting reports, in the form of variance analyses, may indicate where and when there are control lags which could lead to a divergence from the expected results.

The King III report (2009) was more direct under Principle 1.1 regarding control, when it emphasise that companies should be headed by a board that should be in effective control of the company. It also recommended that such a board should issue a statement that they have established a set of formal policies and frameworks for the design and implementation of a system of internal financial controls. The UKCC (FRC, 2010) recommend that, the board should set the company's values and standards and ensure that its obligations to its shareholders are understood and met.

Management control seeks to compare performance to a plan or standard (Roehl-Anderson and Bragg, 2004). Management accounting reports, which are basically, reports on cost and values measured, may serve as strong communication tools among the directors of the board and other stakeholders when monitoring performance. Crowther (2004) observed that the precise nature of the quantitative information given by accounting makes the evaluation of performance a relatively straightforward exercise. Kaplan and Norton (1996) are of the view that the use of measurement as a language helps to translate complex and frequently nebulous concepts into a more precise form. The presentation of management accounting reports which includes financial and non-financial aspects of the company makes the work of the directors in corporate governance easier.

Management accounting reports geared towards control may be presented to show exceptional performance on the identified critical success factors, hence attract the attention of decision makers to institute control measures.
Such reports may be able to show how much the current operation differs from the expected strategy and thereby enable the board to make meaningful decisions about the control action to pursue.

This may be done in well-presented management accounting reports using the following tools:

1. Variance analysis: calculating variances and investigating the reasons why they occurred is used to improve future operating plans (Eldenburgh et al., 2010). Variance analysis may be used to improve future operating plans in order to improve efficiency, profitability and shareholder value of the company.

2. Balanced scorecard: the balanced scorecard approach may present a panoramic view of the entire company and its environment (Kaplan and Nagel, 2004). It shows values created and/or destroyed in all aspects of the company and may therefore enable the board to make quality decisions about how to steer and control their companies at present and in the future.

\section{Approval of major financial decisions}

The King III report (2009) recommend, under Principle 3.1, that boards should have audit committees where the majority of the members are financially literate. The UKCC (FRC, 2010) also suggested that all company boards should have audit committees and that their main responsibilities should be to review the company's internal financial controls and to monitor the integrity of the financial statements on the company's financial performance.

The Sarbanes-Oxley act (2002, Section 1350, d) also stipulates that a financial expert is required on the audit committee or the companies should disclose the reasons for not having such a person. The rationale is to make sure that information contained in any periodic report to the stakeholders, fairly presents, in all material aspects, the financial condition and results of operations of the particular company.

The company's financial management is an integral part of its strategy as any company has to operate within financial constraints and deliver perceived value for money to its stakeholders (Neely, 2002). Crowther (2004) states that managers should not ignore the financial implications of any decisions they make. Naturally, the evaluation of any decision in financial terms is a crucial part of the decision making process.

The management accounting tool of costing may provide information on the level of the finance required, the opportunity cost of retained earnings and the costs associated with raising external finance, whereas cash flow analysis may provide a report on the cash flow from existing operations (Watson and Head, 2006). Management accounting reports to assist the board in investment decision-making include: net present value, internal rate 
Table 1. Management reports based on business performance tools for group or individual evaluations (Adapted from Hulbert and Fitzroy, 2004).

\begin{tabular}{lll}
\hline Performance tool & Subject of evaluation & Management accounting report \\
\hline ROI & Individual directors & $\begin{array}{l}\text { Report to the board showing how much operating income has been } \\
\text { generated using funds controlled by the individual director. }\end{array}$ \\
\hline ROCE & Entire Board & $\begin{array}{l}\text { Report to the shareholders showing how much operating income has been } \\
\text { generated using the total company's investment. }\end{array}$ \\
\hline Residual Income & Entire board & $\begin{array}{l}\text { Report to the investors/shareholders showing how much the board has } \\
\text { exceeded the rate of return required by the investors or providers of capital. }\end{array}$ \\
\hline
\end{tabular}

rate of return and pay-back period which should be able to provide information that makes the long-term impact on management decisions visible (Ansari et al., 1997).

\section{Evaluation of the performance of chief executive officer (CEO) and Directors of the Board}

The King III Report (2009), under Principle 1.23, recommended that improved board performance and effectiveness can be achieved through regular and timely appraisals of the board. The UKCC (FRC, 2010) recommended that the board should undertake a formal and rigorous annual evaluation of its own performance and that of its committees and individual directors.

Neely et al. (2002) state that a performance measurement system enables informed decisions to be made and actions to be taken because it quantifies the efficiency and effectiveness of past actions through acquisition, collation, sorting, analysis and interpretation of appropriate data. A management accounting report using Economic Value Added (EVA ${ }^{\mathrm{TM}}$ ) would be very effective in assisting the board to measure such performance and arriving at a quality decision (Blocher et al., 2010). EVA ${ }^{\mathrm{TM}}$ measures the extent to which the company has increased shareholder value, therefore, if managers focus on EVA ${ }^{\mathrm{TM}}$, it should ensure they operate in a manner consistent with maximising shareholders' wealth (Ehrhardt and Brigham, 2009).

Higgs's (2003) review of non-executive directors made the need for management accounting performance reports very prominent, when he recommended that nonexecutive directors should scrutinise the performance of management in meeting the agreed goals and objectives and to monitor the reporting of performance. This had been argued by Ward (2000), when he states that if a regular, well-planned and unbiased evaluation of the CEO of a company is based on company performance measures and targets, the board can build the result of such evaluation into the remuneration package of the CEO and clearly communicate who is in charge. This is vital since one of the ways whereby the board motivate the CEO to grow shareholder value may be by pegging the remuneration of that CEO to his/her performance.

Leblanc and Gilles (2005) advocate for job descriptions of directors because these ought to provide concise guidelines against which a director's and the board's performance may be measured. Naturally, the board has to be fair when making evaluations. Brickley et al. (2005) state that shareholder value is subject to random factors from outside the company, such as conditions in the general economy-tax rates, level of unemployment and the oil price levels that are largely beyond any individual employee's control. A fair performance report for an individual should therefore focus on the particular individual's performance instead. Hence, a management accounting report which is based on EVA ${ }^{\mathrm{TM}}$ may enable the board to make a fair evaluation of a particular director or the CEO during the period relevant to his/her engagement.

According to Jensen (2005) a correct measure for any person or business unit in a multi-divisional company is determined mainly by two factors namely: 1) the company strategy and 2) the actions that the evaluated person or division can take to contribute to the success of the strategy. Some of the management accounting tools which can be used are: return on investment (ROI); return on capital employed (ROCE); and residual income. Management accounting reports which can be generated using these management accounting tools in group or individual evaluations (Hulbert and Fitzroy, 2004) are shown in Table 1.

\section{Management accounting information for support and counsel of the CEO}

Although, the codes of best practice do not explicitly state the role of boards giving counsel to the CEO, it is well 
implied in the various recommendations. The board is according to FRC (2010) collectively responsible for the success of the company. Since the actions of the CEO, as the major hand of the board of directors, impact on the success of the company, it is reasonably expected that the board should provide the necessary support and counsel to ensure success. Charan (2005) agrees that directors have an obligation to help the new CEO succeed. Cadbury (2002) advised that, chief executives should be able to see their boards as a continually available source of counsel and support, rather than mainly as a monitor and paymaster.

The King III report (2009), after preferring a majority of non-executive directors on the board, under Principle 1.17 , implied the role of counsel and support, while it recommends that the board should have sufficient management information to enable a proper and objective assessment. Both the USKCC (FRC, 2010) and the King III report (2009) agreed that, in general the board including the CEO rely on the secretary of the company who should provide a central source of guidance and advice to the board, and within the company, on matters of ethics and good governance. In supporting the board to give constructive counsel and support to the CEO, the company secretary would therefore work closely with the management accountant to obtain relevant and comprehensive reports to the specific areas which may need counsel.

The King III report (2009) recommends, under Principle 1.6, that the board should have unrestricted access to all company information, records, documents and property. The importance of having access to quality information; is to enable the directors give good counsel and support to the CEO. This fact was recognised by both the King III report (2009) and UKCC (FRC, 2010) when they recommended that if necessary, directors should take independent professional advice at the company's expense. Sussland (2005) stated that, independent management assessments should present the board with an in-depth analysis of the key issues in the internal and external business environment as well as with some insights on the operations of management. From the benchmarking reports, the directors can establish how the company ranks compared to the top performers in the industry and assess their own company's position. Hoque (2006) observed that benchmarking focuses on an ongoing process of measuring and improving products, services and practices against their peers. Benchmarking reports may be of immense benefit to the boards in enabling them to provide counsel and support to the CEO on how to add value to their own company.

\section{Management accounting facilitating compliance to corporate governance requirements}

Compliance to relevant laws, regulations and codes of business practice is one of the cornerstones of good corporate governance. The King III report (2009) is very clear in its recommendation, under Principle 7.4, that the board is responsible for the company's compliance with laws and regulations and should ensure the implementation of an effective compliance framework and processes to execute this task. Among the specific items the directors should include in the company's annual report, according to the King III report (2009), is whether the code of corporate practices and conduct has been adhered to, and if not, reasons should be given for the divergence from the recommendations. The SarbanesOxley act (2002) requires that a statement of compliance be signed by the CEO and the chief financial officer (or equivalent thereof), and it has penalties, for anyone who signs such a statement knowing that they don't conform to all the requirements of the act.

Hattingh (2007) stated that corporate behaviour is defined and informed by principles and ethics that should be hard-coded into the corporate DNA. Management accounting can assist in hard-coding the corporate behaviour by setting and codifying standard behaviour and monitoring the corporate culture by continuous periodic reporting.

Ehrhardt and Brigham (2009) is of the view that management accountants are custodians of ethics. The management accountant, through his/her value definitions may uncover fraud and present reports which reflect realistic value and hence build investors' confidence.

Both the King III report (2009) and the UKCC (FRC, 2010) clearly specify that the board should have a code of ethical conduct and should report to the stakeholders as to what extent the code of ethics has been complied with. Kaplan and Norton (2006) emphasise that the board should ensure that the company managers are operating ethically within the company's code of conduct.

In adhering to the King III report (2009) above, compliance reporting may even take the form of performance reports, that is, regular reports on the implementation of compliance processes and compliance rates as appropriate (Parker, 2002). Some of the management accounting tools used in control may also be used, by the board, to assist in the monitoring and evaluation of the compliance programme.

Variance analysis may be used in compliance reporting. The first step would be to set performance standards in the form of the compliance code. Dasher et al. (2004) stated that performance standards represent the expectations for the activities of the company and that variances are important because management can use them to identify potential inefficiencies. Gable (2006) observed that strong emphasis on reporting has emerged and standards have become central to compliance efforts.

Verschoor (2006) observed that, important outcome measurements include audit or regulatory findings, fines and penalties assessed, and the number and type of customer complaints. 


\section{RESEARCH METHODOLOGY}

The study constituted four parts namely: a literature review, a document review, a questionnaire (Appendix A), and personal interviews (Appendix $B$ ). The document review involved the perusal of publicly available corporate documents such as financial statements and company profiles. The empirical study using the questionnaire and interviews constituted a survey that targeted companies listed on the Botswana Stock Exchange and parastatal companies where the government of Botswana is a large shareholder. Botswana has a small number of companies listed on the Botswana Stock Exchange compared to other developed countries.

All together they are 31 companies (BSE 2009). However, the study assumes that, taken together with the parastatal organisations, these organisations give a fairly accurate picture of corporate governance in Botswana. As the population of study is so small (less than 100), they were all surveyed in a technique known as a census. There was therefore no need for sampling in this group.

The questionnaire aimed to establish the practices of companies related to the nature and extent to which they use management accounting to facilitate corporate governance around the key responsibilities of boards of directors as identified by Kaplan and Nagel (2004).

The questionnaire was made up of five sections (the mini hypotheses of the study), A, B, C, D and E. The contents of each section and their link to the main hypothesis of the study are made in the data analysis and presentation plan (Table 2).

The respondents' profile and the response rate are presented in Table 3. The best response rate was from the financial sector as all the targeted organisations managed to respond. There were 12 respondents from the financial sector, 14 from the parastals, and 21 from other listed companies (excluding the financial sector) this gave a total of 47 respondents. It was from the twelve respondents from the financial sector where interviews were also conducted.

\section{ANALYSIS}

In the following subsections the results from the questionnaires, interviews and documentation review are discussed.

\section{Section A: Strategy approval and monitoring}

The various companies in the study have what they referred to as management accounting departments which provided some management accounting information. However, the study showed that there was an insufficient use of management accounting tools, and the knowledge the directors had of their companies and management is not sufficient. This implied that the companies were not supplied with sufficient management accounting information.

It was further noted that directors' contributions in debates about formulating and monitoring of the company strategy are not sufficient and the company strategy is only discussed every 12 months in the majority of the companies. This made it evident that the boards of directors are not using management accounting information to its full potential.

\section{Section B: Approval of major financial decisions}

The majority of the respondents have audit committees and at least $40 \%$ of the companies' members of the board have specific financial qualifications. However, it was observed that a large percentage of boards of directors don't use common management accounting tools. This implied that management accounting reports are not adequately presented to the board during financial discussions. It was also noted that the board's debate before making major financial decisions is not sufficient in most companies (in $69 \%$ of the respondents). The study concludes that even where some boards do receive management accounting information, the directors in those companies rarely take enough time to utilise the information, hence they tend towards rubber stamping the decisions made by the senior management.

\section{Section C: Evaluation of the CEO and senior executives}

Most companies did not get individual director's performance reports, and therefore evaluations of CEOs and senior management officials are merely done just before the annual general meetings, mainly from the financial results of the operations. The study also noted that many of the directors are seconded to the board by shareholders; hence the periodic assessments do not affect their contracts. This implied the need for management accounting reports as such; boards may take management accounting information produced periodically, as mere detail which they may not require. Hence, management accounting information, in the form of non-financial reports, is not adequately presented to the boards to facilitate decision making.

\section{Section D: Provision of counsel and support to the CEO}

Many companies did not have provisions and funds for directors to source independent advice from experts on certain issues affecting the company. It was also observed that most of the directors were neither sufficiently qualified nor experienced in the sectors of the companies where they were appointed. They could only depend on the quality of the provided management accounting information to offer support and counsel to the CEOs. Unfortunately, the management accounting reports provided were not comprehensive enough to enable the directors to offer support and counsel to the CEOs.

Section E: the use of management accounting information in ensuring compliance

The majority of the companies had some form of a 
Table 2. The data analysis and presentation plan.

\begin{tabular}{|c|c|c|}
\hline $\begin{array}{l}\text { Objective: To investigate the extent to which } \\
\text { the boards of directors use: }\end{array}$ & Mini hypotheses & Analysis \\
\hline \multicolumn{3}{|l|}{ Section A: Strategy approval and monitoring } \\
\hline $\begin{array}{l}\text { Management accounting reports such as Gap } \\
\text { analysis, SWOT analysis, balanced scorecard in } \\
\text { formulating and monitoring of company strategy. }\end{array}$ & $\begin{array}{l}\text { Boards of directors do not use management } \\
\text { accounting information in approving and } \\
\text { monitoring company strategy }\end{array}$ & $\begin{array}{l}\text { To establish whether companies with management accounting } \\
\text { departments monitor their strategies more closely and whether } \\
\text { they employ management accounting reports in doing so. }\end{array}$ \\
\hline \multicolumn{3}{|l|}{ Section B: Approval of major financial decisions } \\
\hline $\begin{array}{l}\text { Management accounting information such as } \\
\text { net present value, internal rate of return, and } \\
\text { payback period in the approval of major } \\
\text { financial decisions. }\end{array}$ & $\begin{array}{l}\text { Boards of directors do not use management } \\
\text { accounting information in approving major } \\
\text { financial decisions. }\end{array}$ & $\begin{array}{l}\text { To establish whether the companies which have more members } \\
\text { with financial qualifications and who receive more management } \\
\text { accounting information such as net present value, internal rate } \\
\text { of return, and payback period are able to constructively debate } \\
\text { financial decisions before approving them. }\end{array}$ \\
\hline \multicolumn{3}{|c|}{ Section C: Evaluation of the CEO and senior executives } \\
\hline $\begin{array}{l}\text { Management accounting information in } \\
\text { evaluation of the senior management and } \\
\text { themselves. }\end{array}$ & $\begin{array}{l}\text { The boards of directors do not use } \\
\text { management accounting information to } \\
\text { evaluate the performance of the senior } \\
\text { management and themselves. }\end{array}$ & $\begin{array}{l}\text { To establish whether the boards which get management } \\
\text { accounting information are more able to make meaningful } \\
\text { evaluation of the CEO, themselves, and senior managers. }\end{array}$ \\
\hline \multicolumn{3}{|c|}{ Section D: Provision of counsel and support to the CEO } \\
\hline $\begin{array}{l}\text { Management accounting information in } \\
\text { provision of counsel and support to the CEO. }\end{array}$ & $\begin{array}{l}\text { Boards of directors do not have access to } \\
\text { management accounting information as a } \\
\text { basis of providing counsel and support to the } \\
\text { CEO. }\end{array}$ & $\begin{array}{l}\text { To determine the extent to which company practice of providing } \\
\text { management accounting reports to directors will impact on the } \\
\text { ability of the boards of directors providing CEOs with support } \\
\text { and counsel. }\end{array}$ \\
\hline \multicolumn{3}{|l|}{ Section E: Ensuring compliance } \\
\hline $\begin{array}{l}\text { Management accounting information in } \\
\text { monitoring and ensuring compliance. }\end{array}$ & $\begin{array}{l}\text { Boards of directors do not ensure } \\
\text { compliance of their company to good } \\
\text { corporate governance. }\end{array}$ & $\begin{array}{l}\text { To determine the impact of companies having management } \\
\text { accounting reports on compliance on their ability to ensure } \\
\text { compliance. }\end{array}$ \\
\hline
\end{tabular}

code of conduct. However, it was realised that, in many of the companies, reports on compliance to the company's code of conduct are not presented periodically to the board. Most respondents only read about compliance in the annual reports prepared by senior management.

It was also observed that most of the reports on compliance were not management accounting oriented, for example, $70 \%$ had never been presented with a cost and benefit report on compliance with the corporate governance guidelines. The study concluded that boards of directors are not given enough management accounting information to assist them in ensuring compliance to their codes.

\section{RECOMMENDATIONS}

Based on the literature review and result from the questionnaire, a set of guidelines were devised to 
Table 3. Respondents' Profile according to organisation.

\begin{tabular}{lccc}
\hline Organisation type & Financial sector & Parastatals & Other listed companies (excluding Financial) \\
\hline No of respondents & 12 & 14 & 21 \\
Percentage response rate & 100 & 74 & 75 \\
Percentage of Total respondents & 26 & 30 & 44 \\
\hline
\end{tabular}

Table 4. Management accounting reporting for corporate governance.

\begin{tabular}{|c|c|c|}
\hline $\begin{array}{l}\text { Directors } \\
\text { responsibilities }\end{array}$ & Decision requirements & Management accounting reports needed \\
\hline $\begin{array}{l}\text { Approve and monitor } \\
\text { company strategy }\end{array}$ & Strategic choice and development & $\begin{array}{l}\text { Environmental analysis } \\
\text { Gap analysis } \\
\text { SWOT analysis } \\
\text { Expected values of alternative strategies }\end{array}$ \\
\hline $\begin{array}{l}\text { Approve major financial } \\
\text { decisions }\end{array}$ & Investment or divestment & $\begin{array}{l}\text { Investment appraisal } \\
\text { Project performance reports }\end{array}$ \\
\hline \multirow[t]{3}{*}{$\begin{array}{l}\text { Evaluate CEO and senior } \\
\text { executive teams }\end{array}$} & $\begin{array}{l}\text { Performance of individual directors and senior } \\
\text { executives }\end{array}$ & $\begin{array}{l}\text { Individual performance reports for directors } \\
\text { and senior managers }\end{array}$ \\
\hline & $\begin{array}{l}\text { To evaluate group performance of senior } \\
\text { executive teams or strategic geographical or } \\
\text { business units }\end{array}$ & $\begin{array}{l}\text { Group performance reports for the board of } \\
\text { directors, major departments or strategic } \\
\text { geographical or business units }\end{array}$ \\
\hline & & $\begin{array}{l}\text { Reports comparing overall company } \\
\text { performance with industrial and economic } \\
\text { performance }\end{array}$ \\
\hline \multirow[t]{3}{*}{$\begin{array}{l}\text { Provide counsel and } \\
\text { support to the CEO }\end{array}$} & $\begin{array}{l}\text { To assist CEO to avoid technical and legal } \\
\text { risks. }\end{array}$ & Benchmarking reports \\
\hline & $\begin{array}{l}\text { To identify emerging trends in business and } \\
\text { keep the CEO and company abreast. }\end{array}$ & $\begin{array}{l}\text { Competitor analysis report. } \\
\text { Continuous periodic environment update } \\
\text { reports }\end{array}$ \\
\hline & $\begin{array}{l}\text { To assist CEO and the company achieve } \\
\text { global competence }\end{array}$ & $\begin{array}{l}\text { Balanced scorecard report on overall } \\
\text { performance }\end{array}$ \\
\hline \multirow[t]{2}{*}{ Ensure compliance } & $\begin{array}{l}\text { To ensure the company complies with the } \\
\text { international corporate governance guidelines }\end{array}$ & Continuous periodic compliance update report \\
\hline & $\begin{array}{l}\text { Whether to diverge from corporate governance } \\
\text { guidelines and provide explanations to the } \\
\text { stakeholders }\end{array}$ & $\begin{array}{l}\text { Report on costs of non-compliance (including } \\
\text { penalties, litigation costs, capital flights etc.) }\end{array}$ \\
\hline
\end{tabular}

\section{Conclusion}

Given the importance of corporate governance and the increased responsibilities that stakeholders place on the shoulders of directors, it would be problematic if directors fail to recognise the importance of management accounting in assisting them to execute their duties efficiently and effectively. Over time management accounting has developed a number of tools that may be used in various decision making situations. 
Boards of directors have unfortunately denied themselves the privilege of these tools by relegating management accounting to the managers and technical staff. Only in some instances, individual directors with financial qualifications or those who have been elevated from senior management level, use these tools and excel in their contributions at the board meetings.

This article recommends that for the directors to execute their duties efficiently, they have to establish strong management accounting departments and call for the management accounting reports from the senior management level up to the board level and regularly use them to facilitate their decision making processes. For every decision the board has to make, there is a need for management accounting information to support it.

Management accountants may need to re-style their presentation to make them less technical without losing the required detail. At the same time, the presentation may need to be user friendly to board members who may not have the necessary financial background. This may make the directors more aware of the benefit of utilising the information hence make meaningful contributions to the board debates and eventually fulfil their duties of delivering effective corporate governance to their companies. However, well prepared reports may not be useful if the directors are not aware of their existence. Therefore, it may be necessary at the time of orientation of the directors for management accountants to present their duties to the board, highlighting the types of reports management accountants can produce to assist the board and how they can be utilised to assist in decision making.

\section{REFERENCES}

Ansari S, Bell J, Klammer T, Lawrence C (1997). Strategy and Management Accounting. Available online at: http://college.hmco.com/accounting/ansari/management/1e/students/ modules/mod11.pdf.

Blocher J, Stout DE, Cokins G (2010). Cost Management: A Strategic Emphasis. $5^{\text {th }}$ Edition. McGraw Hill companies, New York.

Botswana Stock Exchange (BSE). 2009. http://www.bse.co.bw/.

Brewer PC, Garrison RH, Noreen EW (2009). Introduction to Management Accounting. $5^{\text {th }}$ Edition. McGraw-Hill, New York.

Brickley JA, Smith CW, Zimmerman JL (2005). Corporate Governance, Ethics and Organisational Architecture. In: Corporate Governance at Crossroads. Edited by Chew DH, Gillan SL McGraw Hill, New York.

Cadbury A (2002). Corporate Governance and Chairmanship: A Personal View. Oxford University Press, Oxford.

Charan R (2005). Boards that Deliver: Advancing Corporate Governance from Compliance to Competitive Advantage. JosseyBass, San Francisco.

CIMA (2003). The Role of the Non-Executive Director: Making Corporate Governance Work. Available online at: http://www.cimaglobal.com/Documents/ImportedDocuments/NEDSm akingcorpgovwork_techguide_2003.pdf.

CIMA (2005). CIMA Official Terminology. CIMA publishing, London.

Cingula M (2006). Corporate Governance as a Process-oriented Approach to Socially Responsible Organizations. In: International Corporate Governance after Sarbanes-Oxley. Edited by Ali PU, Gregoriou GN. John Wiley and Sons Inc, New Jersey.

Collier PM (2009). Accounting for Managers: Interpreting Accounting Information for Decision-making. $3^{\text {rd }}$ Edition. England John Wiley and
Sons Inc, West Sussex.

Crowther D (2004). Managing Finance: A Socially Responsible Approach. Elsevier, Oxford.

Dasher PE, Strawser JW, Strawser JA (2004). Managerial Accounting. $14^{\text {th }}$ Edition. Dame Thompson Learning, Ohio.

Ehrhardt MC, Brigham EF (2009). Corporate Finance: A Focused Approach. South-Western Cengage Learning, Ohio.

Eldenburgh LG, Wolcott SK, Chen L, Cook G (2010). Cost Management: Measuring Monitoring and Motivating Performance. John Wiley and Sons Inc, New Jersey.

FRC (2010). UK Corporate Governance Code. (Formally the Combined Code) Available online at:http://www.frc.org.uk/documents/pagemanager/Corporate_Govern ance/UK\%20Corp\%20Gov\%20Code\%20June\%202010.pdf.

Freeman RE (2010). Strategic Management a Stakeholder's Approach. Cambridge University Press, Cambridge.

Gable J (2006). Compliance: Where Do We Go From Here? Inform. Manage. J., 40(3): 28-35.

Hattingh B (2007). Hard-code your Corporate Governance into your DNA. The Bottom line. CIMA, Northlands. Issue 46.

Higgs D (2003). The Higgs Report: Review of the role and effectiveness of non-executive directors. [Available online at: http://www.ecgi.org/codes/code.php?code_id=121.

Hoque Z (2006). Strategic Management Accounting Concepts, Processes and Issues. $2^{\text {nd }}$ Edition. Spiro Press, London.

Hulbert J, Fitzroy P (2004). Strategic Management: Creating Value in Turbulent Times. John Wiley and Sons Inc, West Sussex.

Insight (2009). What is CIMA's definition of management accounting? Available online at: http://www.cimaglobal.com/Thoughtleadership/Newsletters/Insight-e-magazine/Insight-2009/Insight-June2009/What-is-CIMAs-definition-of-management-accounting/.

Jensen MC (2005). Value Maximization, Stakeholder Theory, and Corporate Objective Function. In: Corporate Governance at Crossroads. Edited by Chew DH, Gillan SL. McGraw Hill, New York.

Johnson G, Scholes K, Whittington R (2008). Exploring Corporate Strategy: Text and Cases. $8^{\text {th }}$ Edition. Pearson Education, United Kingdom.

Kaplan RS, Nagel ME (2004). Improving Corporate Governance with the Balanced Scorecard. Division of Research: Harvard Business School. Working Paper, 4(44).

Kaplan RS, Norton DP (1996). The Balanced Scorecard: Translating Strategy into Action. Harvard business school press, Boston Massachusetts.

Kaplan RS, Norton DP (2006). Alignment: Using the Balanced Scorecard to Create Synergies. Harvard Business School Press, Boston Massachusetts.

King III Report (2009). The King Report (III) on Corporate Governance for South Africa. Available online at: http://african.ipapercms.dk/IOD/KINGIII/kingiiicode.

Leblanc R, Gilles JM (2005). Inside the Boardroom. John Wiley and Sons, Ontario.

Mepham M (1980). Accounting Models. Polytechnic Publishers Ltd, Stockport.

Neely AD (2002). Business Performance Measurement: Theory and Practice. Cambridge University press, Cambridge.

Neely AD, Adams C, Kennerly M (2002). The performance Prism: the Scorecard for Measuring and Managing Stakeholder Relationship. Prentice Hall, London.

Parker C (2002). The Open Corporation: Self-regulation and Democracy. Cambridge University Press, Cambridge.

Porter ME (1985). Competitive Advantage: Creating and Sustaining Superior Performance. The free press, New York.

Pun KF, White AS (2005). A performance measurement paradigm for integrating strategy formulation: A review of systems and frameworks. Int. J. Manage. Rev, 7(1): 27 - 36.

Roehl-Anderson JM, Bragg SM (2004). Controllership: The work of the Managerial Accountant. John Wiley and sons Inc, New Jersey.

Sarbanes-Oxley Act (2002). Available online at: http://fl1.findlaw.com/news.findlaw.com/cnn/docs/gwbush/sarbanesox ley072302.pdf.

Sussland WA (2005). The Board of Directors: a Referee or Coach? Corp Gov., 5(1): 63 - 71. 
Verhezen P, Morse P (2009). Consensus on global governance principles. J. Int. Bus. Ethics, 2(1): 84 - 93.

Verschoor C (2006). Interactions between Compliance and Ethics. Strateg. Financ., 87(12): 23-25.

Ward RD (2000). Improving Corporate Boards. John Wiley and Sons Inc, New York.
Watson D, Head A (2006). Corporate Finance: Principles and Practice. Prentice Hall Pearson Education Ltd, Essex. 


\section{APPENDIX}

\section{Appendix A : Questionnaire}

Practices Related to the Use of Management Accounting to Facilitate Corporate Governance in Corporations in Botswana

Dear respondent, in responding to the questionnaire your most appropriate response to the questions should be indicated by a tick against the option.

Demography of respondents

1. What is your position in the company?

2. What is the nature of business your company is involved in?

Manufacturing

Services

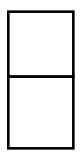

3. What is the size of your company in terms of the number of employees that you have?

1 to 50 From 51 to 100

From 101 to 150

From 151 to 200

200 and above

4. What was the turnover in millions of Pula of your company last year?

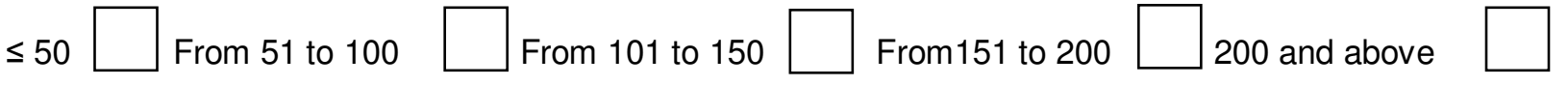

\section{Section A: Strategy approval and monitoring}

1. Does the organisation have personnel in charge of management accounting? Yes

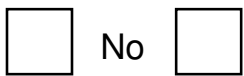

2. The company has an induction programme for newly appointed directors, which covers an overview of the company's operations

Always $\square$ Sometimes $\square$ Rarely $\square$ Never $\square$ I do not know
3. To what extent has the board of directors discussed the current company strategy?
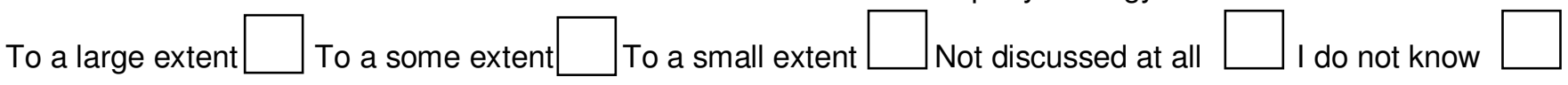

4. How often does the board of directors review the company strategy?
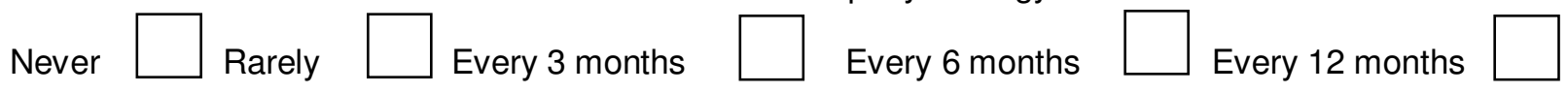

5. How do the directors get supporting information for review of the strategy?

i. Management accounting reports are sent along with the notice and agenda for the meeting

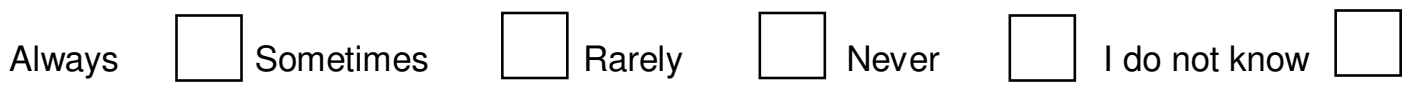

ii. Management accounting reports are presented during the discussions at the time of the meeting?

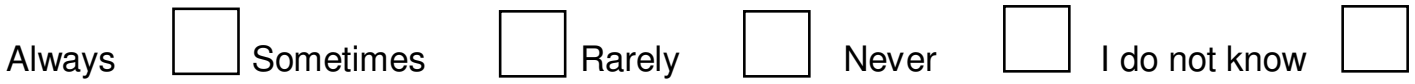


iii. Management accounting reports are provided if and when requested by the directors

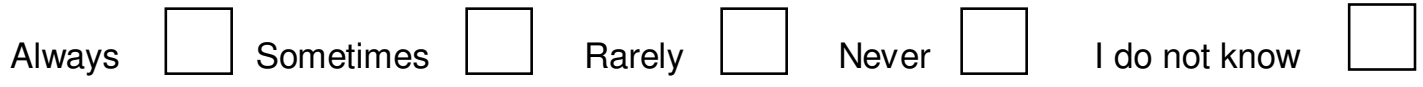

iv. No need for management accounting, issues are discussed as they come in the meetings

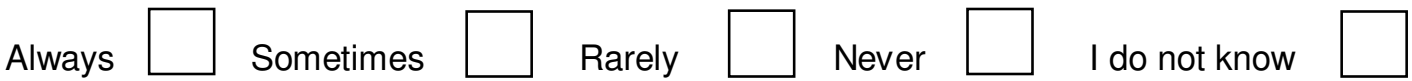

6. Reports on the following aspects are presented to boards of directors.

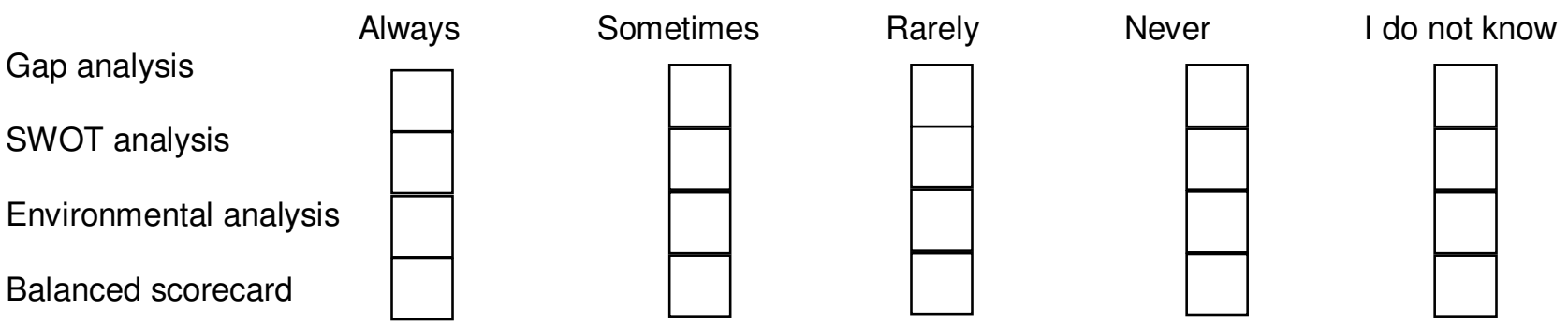

Others (specify)

7. The knowledge the board of directors has about your organisation and its management is

Very sufficient Sufficient

A little bit sufficient Not sufficient at all

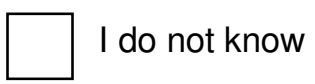

8. Should management accounting reports be presented to directors prior to coming to meetings?

Give reasons for your answer.

9. The contribution of directors on your board to the strategy debates is

Very sufficient Sufficient A little bit sufficient Not sufficient at all

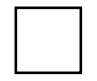
I do not know

\section{Section B: Approval of major financial decisions}

1. Does the board have an audit committee?

2. How many members of your board of directors have the following financial qualifications?

\begin{tabular}{|c|c|c|c|}
\hline & None & $1-3$ & $4-6$ \\
\hline CIMA & & & \\
\hline ACCA & & & \\
\hline Masters in Finance & & & \\
\hline Bachelors in finance & & & \\
\hline AAT & & & \\
\hline
\end{tabular}

Others (specify) 
1. Are there specific financial issues reserved for the board's exclusive consideration, e.g. large financial commitment, capital asset procurement

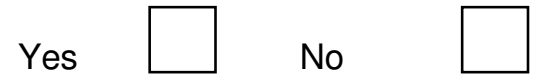

2. Issues related to large financial commitment are reserved for the boards exclusive consideration

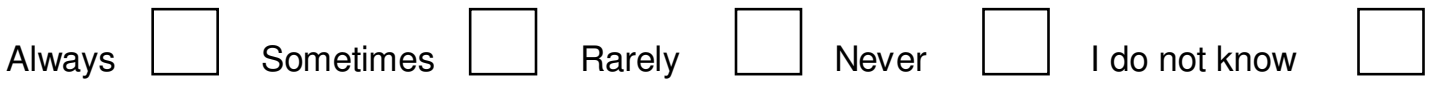

3. Issues related to capital asset procurement are reserved to the boards exclusive consideration

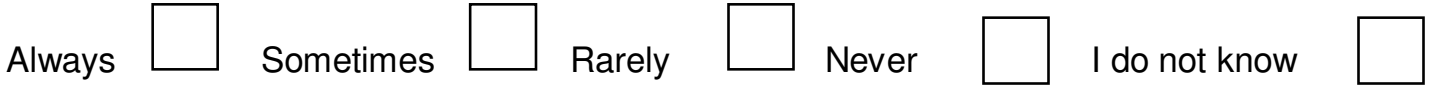

4. Reports on the following aspects are presented to the board of directors during financial discussions

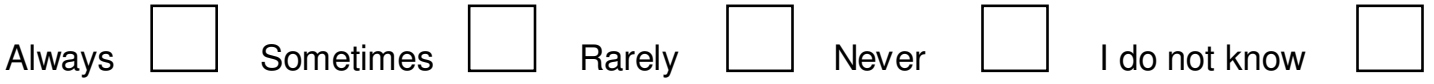

Net Present Value (NPV)

Internal Rate of Return (IRR)

Payback period
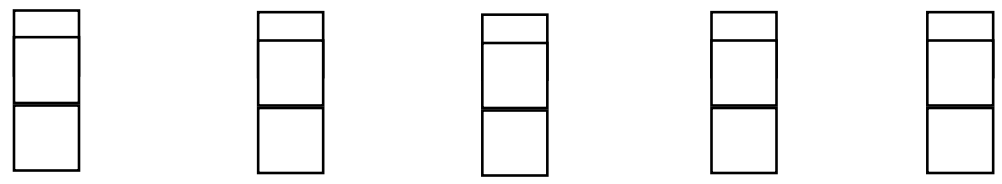

Others (specify)

5. The constructiveness of the debate by the board of directors before making major financial decisions is Very sufficient $\square$ Sufficient $\square$ A little bit sufficient Not sufficient at all I do not know

\section{Section C: Evaluation of CEO, Senior Executives and Boards' performance}

1. Does the board have a recruitment sub-committee?
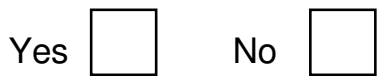

2. If yes how many people sit on the committee?

3. How many members of your current board were put in office in the following way?

After scrutinising their CVs by the recruitment sub- committee

None

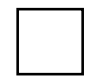

$1-3$

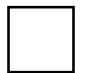

4-6

Over 7

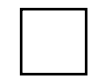

They were seconded to the board by the major shareholders (e.g. government).

None
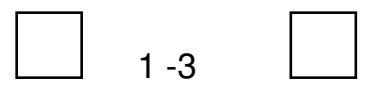

4-6

Over 7

They were solicited from other boards

None

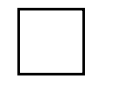

$1-3$

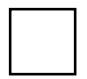

4-6

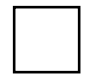

Over 7

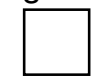


They were head hunted by recruitment agencies

None

$1-3$

4-6

Over 7

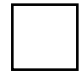

4. Individual performance reports of directors and senior executives are presented to the board prior to the meeting renewing their contracts

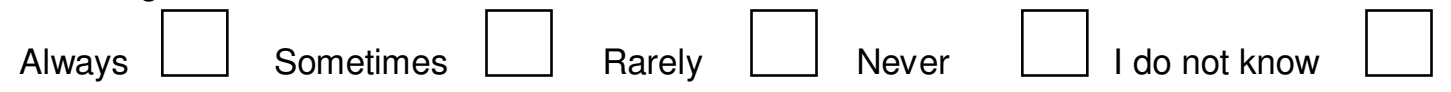

5. How does the board review its own performance? (you may select more than one if applicable)

Prepares a report at the annual general meeting.

Periodically by looking at the critical success factors

No need since the shareholders will determine that by voting

Others (specify below)

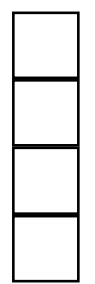

\section{Section D: Provision of Counsel and Support to CEO}

1. The level of business skills of non-executive directors of your organisation is

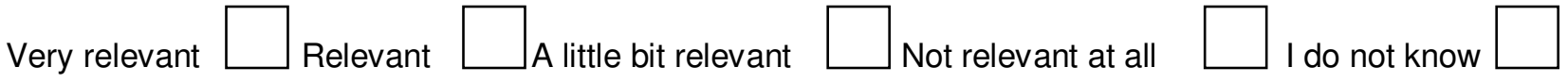

2. The level of experience of non-executive directors in the sector of your organisation is

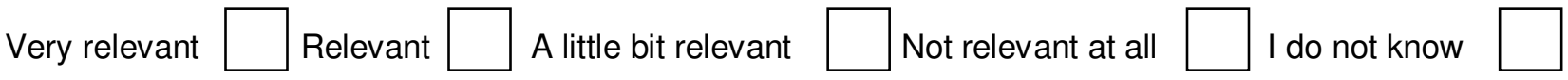

3. How comprehensive are the following reports that are presented to the boards of directors?

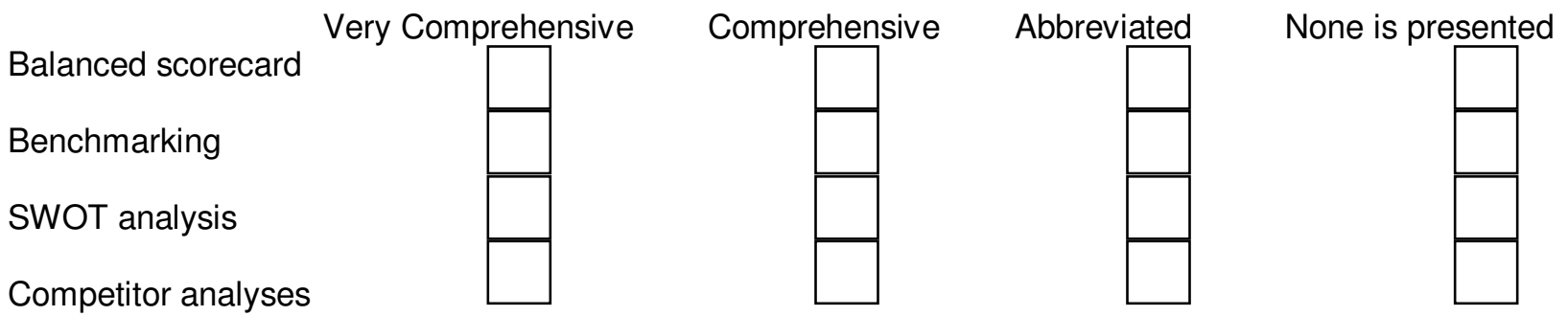

Any other reports presented to the board (specify)

4. Your organisation has provisions for directors to take independent advice on certain issues affecting the company

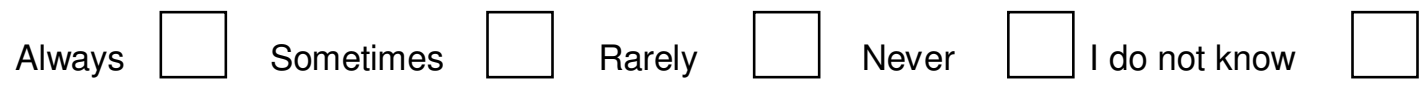

5. Your organisation has funds for directors to take independent advice on certain issues affecting the company

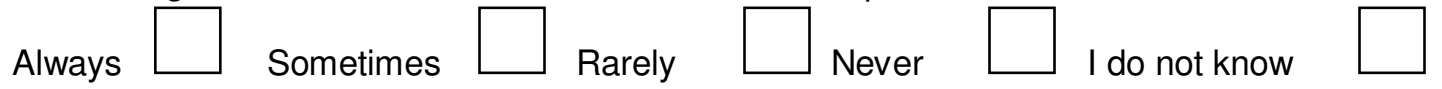


6. The level of the support given by your board of directors to the CEO is Very sufficient $\square$ Sufficient $\square$ A little bit sufficient $\square$ Not sufficient at all $\square$ I do not know $\square$

7. The level of the counsel given by your board of directors to the CEO is Very sufficient $\square$ Sufficient $\square$ A little bit sufficient $\square$ Not sufficient at all $\square$ I do not know $\square$

\section{Section E: Ensuring compliance}

1. Are the operations of your organisation guided by a particular code of conduct?

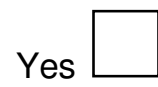

No

2. Reports on compliance to the organisational code of conduct are presented to the board

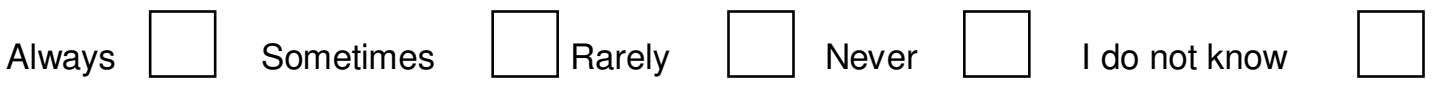

3. Reports on cost and benefit of compliance with the corporate governance guidelines of the industry are prepared Always $\square$ Sometimes $\square$ Rarely $\square$ Never $\square$ I do not know $\square$

4. What types of reports are presented to the board to monitor compliance?

Periodic reports on all areas of compliance

Always Sometimes Rarely Never I do not know

Occasional reports when there is a compliance crisis

End of year general comments in the annual returns on compliance
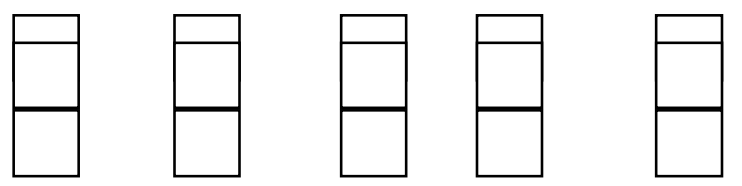

Any other (please specify).

What other issues do you wish to comment on about corporate governance and how the management accounting systems facilitate corporate governance in your organisation?

Issue 1

Issue 2

Issue 3

Please indicate whether you would be interested in the findings of the study and provide your address. 


\section{Appendix B: The Interview guide.}

\section{Part A: Strategy approval and monitoring}

1. Do you feel that your board of directors have sufficient knowledge of your organization and its management?

2. Do you think management accounting reports should be presented to directors before they come to meetings?

3. Do you think most directors on your board are contributing enough to the strategy debates?

\section{Part B: Approval of major financial decisions}

Do you feel that your board of directors carries out constructive debate before making major financial decisions?

\section{Part C: Evaluation of CEO and Senior executives}

How are the directors put in office?

\section{Part D: Provision of counsel and support to the CEO}

1. What types of reports are presented to the board to monitor compliance?

i. Periodic reports on all areas of compliance.

ii. Occasional reports when there is a compliance crisis.

iii. End of year general comments in the annual returns on compliance.

iv. None 